\title{
REKONSTRUKSI KEBUTUHAN HIDUP LAYAK (KHL) MELALUI KOPERASI KARYAWAN DALAM KAJIAN UNDANG - UNDANG NO.13 TAHUN 2003 TENTANG KETENAGAKERJAAN
}

\author{
Nanang Setyono \\ Mahasiswa Program Studi Magister Hukum \\ Universitas Semarang
}

\begin{abstract}
ABSTRAK
Pemerintah telah mengatur setiap pekerja berhak memperoleh penghasilan yang memenuhi penghidupan yang layak bagi kemanusiaan (pasal 88 ayat 1 UU No. 13 tahun 2003), hal ini yang kemudian dijadikan dasar penentuan kebijakan pengupahan, salah satunya adalah penentuan upah minimum yang didasarkan pada penentuan kebutuhan hidup layak dan dengan memperhatikan produktivitas serta pertumbuhan ekonomi yang dirumuskan melalui Dewan Pengupahan (yang unsurnya terdiri dari Pakar, Pekerja, Pengusaha dan Pemerintah). Namun dalam implementasi kebijakan tersebut tidak berjalan mudah dan mulus karena dalam mendefinisikan unsur-unsur kebutuhan hidup layak pun selalu terdapat perbedaan sudut pandang, sehingga dalam merekomendasikan hasil rumusan upah dewan pengupahan seringkali tidak memuat rekomendasi yang satu suara terkait rumusan pengupahan namun berisi pendapat masing-masing (pekerja dan pengusaha) dalam merumuskan upah.

Penelitian ini dilakukan dengan menggunakan metode yuridis normatif, dimana dengan bahan pustaka yang ada coba diteliti bagaimana das sollen dan das sein nya terkait penentuan upah minimum yang didasarkan pada standart kebutuhan hidup layak yang akan diuji dengan beberapa teori yaitu teori kesejahteraan, teori keadilan, teori dan prinsip koperasi.

Kebutuhan hidup layak dirumuskan oleh dewan pengupahan kabupaten/kota dan dewan pengupahan provinsi yang direkomendasikan kepada gubernur sebagai dasar pertimbangan penetapan upah. Upah minimum kabupaten/kota dan upah minimum provinsi tersebut diperuntukkan bagi pekerja atau buruh lajang. Dalam upaya meningkatkan kesejahteraannya, pekerja/ buruh dapat membentuk koperasi karyawan yang difasilitasi oleh pengusaha. Keberadaan koperasi karyawan tidak hanya bisa memenuhi komponen kebutuhan hidup yang dimaksud didalam PP No.78 tahun 2015 tentang pengupahan Jo. Permenaker No.21 tahun 2016 tentang Kebutuhan hidup layak tetapi keberadaan koperasi karyawan juga dapat menjawab kebutuhan hidup riil pekerja dan keluarganya diluar komponen kebutuhan hidup layak.
\end{abstract}

Kata kunci: kebutuhan hidup layak, koperasi, karyawan. 


\begin{abstract}
The government has arranged for every worker to have the right to obtain income that fulfills decent livelihoods for humanity (Article 88 paragraph 1 of Law No. 13 year 2003), which is then used as the basis for determining wage policy. One of the policies is the determination of minimum wages based on determining living necessities feasible and by paying attention to productivity and economic growth formulated through the Wage Council (whose elements consist of Experts, Workers, Entrepreneurs and Government). However, the implementation of the policy did not run easily and smoothly because in defining the elements of decent living there were always different points of view. Therefore, in recommending the wage formulation, the wage council often did not contain one vote recommendations related to wage formulas but contained opinions of each (workers and employers) in formulating wages.

This research was conducted by using normative juridical method, where with the existing literature try to examine how das sollen and das sein related to the determination of minimum wages based on the standard of decent living needs to be tested with several theories namely welfare theory, justice theory, theory and cooperative principle.

Decent living needs are formulated by the regency/city wage council and the provincial wage council recommended to the governor as a basis for consideration of wage setting. District/city minimum wages and provincial minimum wages are for single workers or laborers. In an effort to improve their welfare, workers/laborers can form employee cooperatives facilitated by entrepreneurs. The existence of an employee cooperative can not only fulfill the components of life necessities referred to in PP No. 78 year 2015 concerning wages jo. Minister of Manpower Regulation No.21 year 2016 concerning the need for decent living but the existence of cooperative employees can also answer the real life needs of workers and their families outside the components of decent living needs.
\end{abstract}

Keywords: the need for decent living, cooperatives, employees. 


\section{PENDAHULUAN}

\section{A. LATAR BELAKANG}

Problematika

ketenagakerjaan/perburuhan

sepanjang masa tidak pernah selesai, dari masalah perlindungan, pengupahan, kesejahteraan, perselisihan hubungan industrial, pembinaan, dan pengawasan ketenagakerjaan. $\mathrm{Hal}$ ini lebih diakibatkan kelemahan pemerintah secara sistemik dalam mengimplementasikan undangundang ketenagakerjaan, bahkan cenderung ada penyimpangan, hal lain masalah koordinasi dan kinerja antar lembaga pemerintah belum optimal dan masih sangat memprihatinkan. ${ }^{1} \quad$ Undang Undang Dasar 1945 pasal 27 menetapkan bahwa tiap warga negara berhak atas pekerjaan dan penghidupan yang layak bagi kemanusiaan. $^{2}$ Ini berarti keharusan Upah adalah pembayaran yang diterima buruh selama ia melakukan pekerjaan atau dipandang melakukan pekerjaan. $^{3}$ Bagi pekerja/ buruh upah adalah jumlah uang yang diterimanya pada waktu tertentu atau lebih penting lagi adalah: jumlah barang kebutuhan hidup yang dapat ia beli dari jumlah upah itu. $^{4}$

Pemerintah telah terlibat
dalam menangani masalah
pengupahan melalui berbagai
kebijakan yang dituangkan dalam
peraturan perundang-undangan.

${ }^{1}$ Adrian Sutedi, Hukum Perburuhan, Sinar Grafika, Jakarta, 2011, hal. 142.

${ }^{2}$ Ibid, Hlm. 138

${ }^{3}$ Ibid, HIm. 129

${ }^{4}$ Zaeny Asyhadie, Op Cit, HIm.76
Dalam Undang-Undang No. 13

Tahun 2003 tentang

Ketenagakerjaan Pasal 88 ayat 1 , disebutkan bahwa setiap pekerja/buruh berhak memperoleh penghasilan yang memenuhi penghidupan yang layak bagi kemanusiaan. Untuk maksud tersebut, maka pemerintah menetapkan kebijakan pengupahan untuk melindungi pekerja/buruh. Berdasarkan Pasal 1 angka 2 Undang - Undang No. 13 Tahun 2003 tentang Ketenagakerjaan, yang dimaksud dengan Pekerja/Buruh adalah setiap orang yang bekerja dengan menerima upah atau imbalan dalam bentuk lain. Salah satu kebijakan pengupahan yang diberikan pemerintah adalah penetepan upah minimum. Pemerintah menetapkan upah minimum berdasarkan kebutuhan hidup layak dan dengan memperhatikan produktivitas dan pertumbuhan ekonomi. Upah minimum tersebut dapat berupa :

a. upah minimum berdasarkan wilayah provinsi atau kabupaten/kota;

b. upah minimum berdasarkan sektor pada wilayah provinsi atau kabupaten/kota.

Upah

minimum sebagaimana dimaksud di atas diarahkan kepada pencapaian kehidupan yang layak. Pengusaha dilarang membayar upah lebih rendah daripada minimum. Pengaturan pengupahan yang ditetapkan atas kesepakatan antara pengusaha dan pekerja/buruh atau serikat pekerja/serikat buruh tidak boleh lebih rendah dari ketentuan 


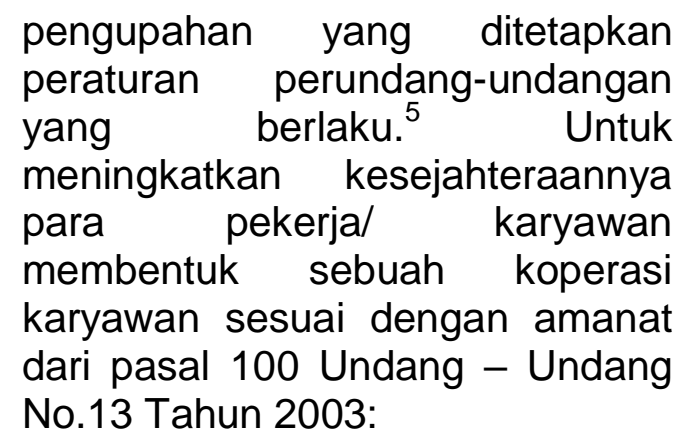

1. Untuk meningkatkan kesejahteraan bagi pekerja/buruh dan keluarganya, pengusaha wajib menyediakan fasilitas kesejahteraan;

2. Penyediaan fasilitas kesejahteraan sebagaimana dimaksud dalam ayat (1), dilaksanakan dengan memperhatikan kebutuhan pekerja/buruh dan ukuran kemampuan perusahaan;

3. Ketentuan mengenai jenis dan kriteria fasilitas kesejahteraan sesuai dengan kebutuhan pekerja/buruh dan ukuran kemampuan perusahaan sebagaimana dimaksud dalam ayat (1) dan ayat (2), diatur dengan Peraturan Pemerintah.

Dan berdasarkan pasal 101 Undang - Undang No.13 Tahun 2003 baik pekerja/buruh, serikat pekerja, Pengusaha maupun pemerintah untuk membentuk badan usaha/ koperasi untuk meningkatkan kesejahteraan pekerja adapun bunyi dari pasal 101 adalah:
1. Untuk meningkatkan kesejahteraan

pekerja/buruh, dibentuk koperasi pekerja/buruh dan usaha - usaha produktif di perusahaan.

2. Pemerintah, pengusaha, dan pekerja/buruh atau serikat pekerja/serikat buruh berupaya menumbuh kembangkan koperasi pekerja/buruh, dan mengembangkan usaha produktif sebagaimana dimaksud dalam ayat (1).

3. Pembentukan koperasi sebagaimana dimaksud dalam ayat (1), dilaksanakan sesuai dengan peraturan perundang-undangan yang berlaku.

4. Upaya - upaya untuk menumbuh kembangkan koperasi pekerja/buruh sebagaimana dimaksud dalam ayat (2), diatur dengan Peraturan Pemerintah. ${ }^{6}$

\section{RUMUSAN MASALAH}

Berdasarkan latar belakang di atas, maka dapatlah dirumuskan permasalahanpermasalahan sebagai berikut:

1) Bagaimana Konstruksi KHL sesuai dengan Undang Undang No. 13 Tahun 2003?

2) Bagaimana Rekonstruksi KHL melalui Koperasi Karyawan dalam kajian

5 Lalu Husni, Hukum Ketenagakerjaan Indonesia, Edisi Revisi, Rajawali Pers, Jakarta, 2010, hlm. 159

\footnotetext{
6 UU No. 13 Tahun 2003 Tentang Ketenagakerjaan
} 
Undang - Undang No. 13

Tahun 2003?

III. PEMBAHASAN

\section{A. Konstruksi KHL Berdasarkan Undang - Undang No. 13 Tahun 2003}

dalam menangani masalah pengupahan melalui berbagai kebijakan yang dituangkan dalam peraturan perundang-undangan. Dalam Undang-Undang No. 13 Tahun 2003 tentang Ketenagakerjaan, pasal 88 ayat 1 , disebutkan bahwa setiap pekerja/ buruh berhak memperoleh penghasilan yang memenuhi penghidupan yang layak bagi kemanusiaan. Untuk maksud tersebut, maka pemerintah menetapkan kebijakan pengupahan untuk melindungi pekerja/ buruh. Berdasarkan Pasal 1 angka 2 Undang - Undang No. 13 Tahun 2003 tentang Ketenagakerjaan, yang dimaksud dengan pekerja/buruh adalah setiap orang yang bekerja dengan menerima upah atau imbalan dalam bentuk lain. Upah adalah diskursus yang sangat sensitif, sehingga Pemerintah harus mengambil peran dalam menentukan kebijakan tentang pengupahan, salah satu kebijakan pengupahan yang diberikan pemerintah adalah penetepan upah minimum.

Pemerintah menetapkan upah minimum berdasarkan kebutuhan hidup layak dan dengan memperhatikan produktivitas dan pertumbuhan ekonomi. Upah minimum tersebut dapat berupa : a. upah minimum berdasarkan wilayah provinsi atau kabupaten/kota;

b. upah minimum berdasarkan sektor pada wilayah provinsi atau kabupaten/kota. Upah minimum sebagaimana dimaksud di atas diarahkan kepada pencapaian kehidupan yang layak. Pengusaha dilarang membayar upah lebih rendah daripada minimum. Pengaturan pengupahan yang ditetapkan atas kesepakatan antara pengusaha dan pekerja/ buruh atau serikat pekerja/serikat buruh tidak boleh lebih rendah dari ketentuan pengupahan yang ditetapkan peraturan perundangundangan yang berlaku.

Sistem pengupahan merupakan kerangka bagaimana upah diatur dan ditetapkan. Sistem pengupahan di Indonesia pada umumnya didasarkan kepada tiga fungsi upah yaitu:

1) Menjamin kehidupan yang layak bagi pekerja/buruh dan keluarganya;

2) Mencerminkan imbalan atas hasil;

3) Menyediakan insentif untuk mendorong peningkatan produktifitas kerja. ${ }^{8}$

\section{A.1. Hierarki Peraturan Kebijakan KHL}

Sistem pengupahan didalam Undang - Undang No. 13 Tahun 2003 tentang

\footnotetext{
${ }^{7}$ Lalu Husni, op. cit. hlm. 159

8 Simanjuntak Payaman J, Pengantar Ekonomi Sumber Daya Manusia, (Jakarta : Lembaga Penerbit Fakultas Ekonomi Universitas Indonesia, 1985), hlm.110.
} 
ketenagakerjaan secara khusus disebutkan pada pasal 88 sampai dengan pasal 98 . sedangkan diperaturan lainnya bisa dilihat pada Kepres No. 107 tahun 2004 tentang Dewan Pengupahan

Nasional, Permenaker No. 21 tahun 2016 tentang Kebutuhan Hidup Layak dan Peraturan Pemerintah No. 78 tahun 2015 tentang Pengupahan belum termasuk peraturan daerah provinsi yang menetapkan besaran upah minimum di masing-masing kota.

Sebelum menganalisis lebih dalam tentang kebutuhan hidup layak yang menjadi dasar kebijakan pengupahan, perlu kiranya kita melihat struktur hierarki peraturan dan kebijakan yang menyangkut kebutuhan hidup layak menurut tata urutan perundangundangan pada UndangUndang nomor 12 tahun 2011 tentang Pembentukan Peraturan Perundangundangan, hal ini penting dilakukan untuk memastikan kesesuaian antara jenis, hierarki, dan materi muatan yang merupakan asas pembentukan peraturan perundangan. Pasal 7 ayat (1 dan 2) Undang-Undang nomor 12 tahun 2011 tentang Pembentukan Peraturan Perundang-Undangan menyebutkan:

(1) Jenis dan hierarki Peraturan Perundangundangan terdiri atas:
a. Undang-Undang Dasar Negara Republik

Indonesia Tahun 1945;

b. Ketetapan Majelis

Permusyawaratan

Rakyat;

c. UndangUndang/Peraturan

Pemerintah Pengganti Undang-Undang;

d. Peraturan Pemerintah;

e. Peraturan Presiden;

f. Peraturan Daerah Provinsi; dan

g. Peraturan Daerah Kabupaten/Kota.

(2) Kekuatan hukum Peraturan Perundang-undangan sesuai dengan hierarki sebagaimana dimaksud pada ayat (1).

Sebagaimana juga disebutkan dalam pasal 3 Undang-Undang nomor 12 tahun 2011 tentang Pembentukan Peraturan Perundang-Undangan dimana menyebutkan bahwa UndangUndang Dasar Negara Republik Indonesia Tahun 1945 merupakan hukum dasar dalam Peraturan Perundang-undangan, sehingga dalam pengaturan dasar dari kebutuhan hidup layak bisa kita pastikan terlebih dahulu di UndangUndang Dasar Negara Republik Indonesia Tahun 1945. Perintah UU. No. 13 tahun 2003 tentang Ketenagakerjaan yang mengatur tentang kebutuhan hidup layak yang menjadi dasar penghitungan kebijakan pengupahan dijalankan melalui Peraturan Pemerintah No. 78 tahun 2015 tentang Pengupahan selanjutnya melalui atribusi Menteri Ketenagakerjaan mengeluarkan Peraturan Menteri Ketenagakerjaan No. 21 tahun 2016 tentang Kebutuhan Hidup Layak. Kewenangan atribusi menurut Indroharto adalah pemberian 
wewenang pemerintahan yang baru oleh suatu ketentuan dalam peraturan perundang-undangan. ${ }^{9}$

Disisi lain pasal 8 UndangUndang nomor 12 tahun 2011 tentang Pembentukan Peraturan PerundangUndangan menyebutkan :

(1) Jenis Peraturan Perundangundangan selain sebagaimana dimaksud dalam Pasal 7 ayat (1) mencakup peraturan yang ditetapkan oleh Majelis Permusyawaratan Rakyat, Dewan Perwakilan Rakyat, Dewan Perwakilan Daerah, Mahkamah Agung, Mahkamah Konstitusi, Badan Pemeriksa Keuangan, Komisi Yudisial, Bank Indonesia, Menteri, badan, lembaga, atau komisi yang setingkat yang dibentuk dengan Undang-Undang atau Pemerintah atas perintah Undang-Undang,

Dewan Perwakilan Rakyat Daerah Provinsi, Gubernur, Dewan Perwakilan Rakyat Daerah Kabupaten/Kota, Bupati/Walikota, Kepala Desa atau yang setingkat.

(2) Peraturan Perundang-undangan sebagaimana dimaksud pada ayat (1) diakui keberadaannya dan mempunyai kekuatan hukum mengikat sepanjang diperintahkan oleh Peraturan Perundangundangan yang lebih tinggi atau dibentuk berdasarkan kewenangan.

Peraturan

Menteri

Ketenagakerjaan No. 21 tahun 2016 tentang Kebutuhan Hidup Layak berdasarkan pasal 8 Undang-Undang nomor 12 tahun 2011 tentang

\footnotetext{
${ }^{9}$ Indroharto, Usaha Memahami UndangUndang Tentang Peradilan Tata Usaha Negara, Jakarta, Pustaka Harapan, 1993, hIm 68.
}

Pembentukan Peraturan PerundangUndangan mempunyai kekuatan hukum mengikat karena diperintahkan oleh peraturan perundang-undangan.

Setelah kita pahami tentang hierarki peraturan dan kebijakan kebutuhan hidup layak, selanjutnya kita akan coba paparkan kontruksi kebutuhan hidup layak berdasarkan UU. No. 13 tahun 2003 tentang Ketenagakerjaan berikut peraturan kebijakan dibawahnya untuk menjadi telaah. Seperti yang telah dipahami pada table 1 diatas bahwa upah minimum diarahkan pada pencapaian kebutuhan hidup layak. ${ }^{10}$ Sedangkan terkait dengan kebijakan pengupahan diatur melalui Peraturan Pemerintah dalam hal ini adalah Peraturan Pemerintah No. 78 tahun 2015 tentang Pengupahan dan secara lebih terperinci pengaturan tentang kebutuhan hidup layak terdapat pada Peraturan Menteri Ketenagakerjaan No. 21 tahun 2016 tentang Kebutuhan Hidup Layak jo. Peraturan Menteri Ketenagakerjaan Nomor 13 Tahun 2012 Tentang Komponen Dan Pelaksanaan Tahapan Pencapaian Kebutuhan Hidup Layak.

\section{A.2. Pergeseran Makna KHM Ke KHL}

Sejarah telah mencatat bahwa sebelum pertengahan akhir 2015 telah terjadi tiga kali perubahan kebijakan upah minimum. ${ }^{11}$ Perubahan

\footnotetext{
${ }^{10}$ Pasal 89 ayat (2) UU. No. 13 tahun 2003 tentang Ketenagakerjaan

${ }_{11}$ Pertama, Kebijakan upah minimum diberlakukan berdasarkan Kebutuhan Fisik Minimum (KFM), kebijakan ini berlaku pada tahun 1969 - 1995. Kedua, Kebijakan upah minimum berdasarkan Kebutuhan Hidup Minimum (KHM) yang berlaku pada tahun 1996 - 2005. Ketiga, Kebijakan upah minimum berdasarkan Kebutuhan Hidup
} 
kebijakan tersebut pada dasarnya merupakan konsekuensi logis dari upaya mendorong agar upah dapat membawa pekerja dalam taraf hidup layak. Kajian mengenai hidup layak semakin gencar dilakukan pada awal masa reformasi sehingga menghasilkan Permenaker No. 17/VIII/2005.

Adanya peraturan ini sekaligus mengubah kebijakan upah minimum yang semula didasarkan pada Kebutuhan Hidup Minimum (KHM) beralih kepada KHL. Dalam peraturan tersebut juga disebutkan 49 komponen KHL. $^{12}$ Kajian mengenai $\mathrm{KHL}$ terus berlanjut, bahkan pengertian $\mathrm{KHL}$ mengalami pergeseran makna. Dalam Menteri Ketenagakerjaan Nomor 13 Tahun 2012 Tentang Komponen Dan Pelaksanaan Tahapan Pencapaian Kebutuhan Hidup Layak tersebut diatas masih menjadi acuan dalam menentukan komponen $\mathrm{KHL}$ karena dalam ketentuan penutup pasal 14 Peraturan Menteri Ketenagakerjaan No. 21 tahun 2016 tentang Kebutuhan Hidup Layak, disebutkan :

"Pada saat Peraturan Menteri ini berlaku, ketentuan selain pasal 2 dan lampiran 1 Peraturan Menteri Ketenagakerjaan Nomor 13 Tahun 2012 Tentang

Layak yang berlaku pada tahun 2005-2015. Lihat Sinaga, T, "Kebijakan Pengupahan di Indonesia", Jurnal Ketenagakerjaan, Volume 3, Februari 2008, hlm. 88-102

${ }^{12} 49$ komponen ini merupakan penjabaran dari tujuh kelompok daftar kebutuhan yang meliputi 1) Makanan dan Minuman, 2) Sandang, 3) Perumahan, 4) Pendidikan, 5) Kesehatan, 6) Transportasi, dan 7) Rekreasi dan Tabungan. Lihat Lampiran 1 Permenakertas No.17/Men/VIII/2005
Komponen Dan Pelaksanaan Tahapan Pencapaian Kebutuhan Hidup Layak (Berita Negara Republik Indonesia Tahun 2012 Nomor 707), dicabut dan dinyatakan tidak berlaku."

\section{A.3. Kelayakan Upah Minimum Terhadap Pekerja}

Pasal 1 angka 1 Peraturan Menteri Ketenagakerjaan No. 21 tahun 2016 tentang Kebutuhan Hidup Layak memberikan definisi kebutuhan hidup layak :

"Kebutuhan hidup layak yang selanjutnya disingkat $\mathrm{KHL}$ adalah standar kebutuhan seorang pekerja/buruh lajang untuk dapat hidup layak secara fisik dalam 1 (satu) bulan."

Upah minimum yang ditetapkan baik upah minimum Provinsi atau Kabupaten/ Kota baik yang diuraikan untuk pencapaian $\mathrm{KHL}$ maupun yang ditetapkan berdasarkan $\mathrm{KHL}$ merupakan standar kebutuhan untuk seorang pekerja/buruh yang masih lajang (tanpa tanggungan) seperti disebut dalam definisi $\mathrm{KHL}$ diatas, sehingga benar-benar hanya merupakan kebutuhan dasar yang relatif layak secara personal. Menurut Silaban (2012) yang dikutip dalam Tulus T.H. Tambunan menyatakan bahwa upah minimum yang didasarkan pada $\mathrm{KHL}$ yang ditujukan untuk pekerja/buruh lajang tidak relevan jika dikaitkan dengan upah layak. Sasaran KHL bagi pekerja/buruh lajang berperan sebagai jaring pengaman sosial, dimana konsep tersebut berbeda 
dengan konsep upah layak. ${ }^{13}$

Dengan demikian, agar dapat mewujudkan keadilan dan upah layak maka penerapan $\mathrm{KHL}$ sebagai dasar UMP tidak diberlakukan secara universal, dan perlu optimalisasi pemberlakuan skala upah bagi seluruh pekerja/ buruh yang tidak lajang.

Komponen KHL sebagai pedoman terhadap penetapan UMP yang sesuai dengan kebutuhan riil di lapangan. Akan tetapi, komponen $\mathrm{KHL}$ dari setiap rezim regulasi kebijakan pemerintah selalu memperoleh pertentangan dari pekerja/buruh. Tingginya tuntutan $\mathrm{KHL}$ oleh serikat pekerja yang menjadi dasar penetapan upah seringkali tidak diiringi dengan produktivitas pekerja/buruh itu sendiri. Kondisi tersebut yang sering menjadi persengketaan mengenai penetapan upah yang sesuai dan adil untuk kedua belah pihak yaitu pengusaha dan pekerja/ buruh.

\section{A.4. Penetapan Upah Minimum Untuk Pencapaian KHL}

Pemerintah memutuskan untuk menetapkan formula penentuan upah minimum pekerja yang sederhana dan terukur. Sistem ini dituangkan dalam Peraturan Pemerintah No. 78 Tahun 2015 Tentang Pengupahan. Adapun formulasi pengupahan sebagaimana disebutkan dalam pasal 44 ayat (2) PP No. 78 Tahun 2015 adalah:

Formula perhitungan Upah minimum sebagaimana dimaksud dalam ayat

13 Tulus T,H, Tambunan, Globalisasi dan Perdagangan Internasional, (Jakarta: Ghalia Indonesia), 2015, HIm 268 sebagai berikut : $\mathrm{UM}_{\mathrm{n}}=\mathrm{UM}_{\mathrm{t}}+$ $\left\{U_{\mathrm{t}} \times\left(\right.\right.$ Inflasi $+\% \Delta$ PDB $\left.\left._{\mathrm{t}}\right)\right\}$.

Dari Pasal tersebut dapat terlihat bahwa dasar untuk menentukan formulasi upah minimum adalah dengan upah minimum tahun berjalan. Upah minimum tersebut telah merefeksikan KHL yang sudah dikaji Dewan Pengupahan Daerah sejak tahun sebelumnya. Evaluasi $\mathrm{KHL}$ akan dilakukan setiap lima tahun sekali karena berdasarkan survei Badan Pusat Statistik (BPS), perubahan pola konsumsi masyarakat terjadi setiap lima tahun.

Namun demikian, kebijakan pemerintah ini sepertinya tidak berjalan mulus. Kalangan pekerja menyatakan penolakannya terhadap kebijakan tersebut. Pekerja menilai penggunaan sistem formula tetap dalam penetapan upah minimum akan membatasi kenaikan upah minimum pekerja di angka 10\% maksimal. Misalnya, kenaikan upah minimum tahun 2018 di Kota Semarang adalah upah minimum tahun berjalan sebesar Rp.2.125.000 ditambah inflasi sebesar $5 \%$ ditambah pertumbuhan ekonomi $4,67 \%$, maka kenaikan hanya sebesar $9.67 \%$. Kondisi ini jauh dari harapan pekerja.

Pekerja juga menyoroti survei $\mathrm{KHL}$ yang selama ini dilakukan oleh Dewan Pengupahan Provinsi atau Dewan Pengupahan Kabupaten/Kota dengan membentuk tim survei yang terdiri dari unsur tripartit dan unsur dari perguruan tinggi/pakar yang jumlahnya sesuai kebutuhan.

Dengan formula pengupahan baru, muncul kekhawatiran bahwa keterwakilan serikat pekerja dalam tim survei Dewan Pengupahan hanya menjadi formalitas untuk memenuhi kewajiban sesuai aturan yang berlaku. 
Selain itu, peninjauan komponen $\mathrm{KHL}$ dalam jangka waktu 5 tahun sekali, akan berdampak pada ketidaksesuaian nilai komponen $\mathrm{KHL}$ dengan kebutuhan riil masyarakat yang mudah berubah.

\section{A.5. Penetapan KHL Oleh Dewan Pengupahan}

Penetapan Upah Minimum
yang menjadi kewenangan
pemerintah dalam hal ini adalah
Gubernur perlu dibentuk adanya
Dewan Pengupahan yang diatur
dalam Pasal 98 ayat (1) dan ayat (2)
Undang-undang nomor 13 tahun 2003
tentang Ketenagakerjaan:

"Untuk memberikan saran, pertimbangan, dan merumuskan kebijakan pengupahan yang akan ditetapkan oleh pemerintah, serta untuk pengembangan sistem pengupahan nasional dibentuk Dewan Pengupahan Nasional, Propinsi dan Kabupaten/Kota".

Ayat (2) : "Keanggotaan Dewan Pengupahan sebagaimana dimaksud pada ayat (1) terdiri dari unsur pemerintah, organisasi pengusaha, serikat pekerja/serikat buruh, perguruan tinggi dan pakar."

Ayat (3) : "Keanggotaan Dewan Pengupahan tingkat Nasional diangkat dan diberhentikan oleh Presiden, sedangkan keanggotaan Dewan Pengupahan Propinsi, Kabupaten/Kota diangkat dan diberhentikan oleh

Gubernur/Bupati/Walikota."

Ketentuan mengenai tata cara pembentukan, komposisi keanggotaan, tata cara pengangkatan dan pemberhentian keanggotaan, serta tugas dan tata kerja Dewan Pengupahan sebagaimana dimaksud pada ayat (1) dan ayat (2) diatur dengan Keputusan Presiden hal ini disebutkan dalam Pasal 98 ayat (4) Undang-undang nomor 13 tahun 2003 tentang Ketenagakerjaan.

$\mathrm{KHL}$ sebagai dasar dalam penetapan Upah Minimum merupakan peningkatan dari kebutuhan hidup minimum (KHM) yang besarnya diperoleh melalui survei harga. Survei harga dilakukan oleh tim yang terdiri dari unsur tripartit yang dibentuk oleh Ketua Dewan Pengupahan Provinsi dan/atau Kabupaten/Kota. Dewan Pengupahan Provinsi atau Kabupaten/Kota adalah suatu lembaga non struktural yang bersifat tripartit, dibentuk oleh Gubernur/ Bupati/ Walikota dan bertugas memberikan saran serta pertimbangan kepada Gubernur/ Bupati/ Walikota dalam penetapan Upah Minimum.

Dan dalam Pasal 22 Keputusan Presiden No. 107 Tahun 2004 tentang Dewan Pengupahan yaitu :

"Dalam melaksanakan tugas, Dewan Pengupahan Provinsi dapat bekerja sama, baik dengan instansi Pemerintah maupun swasta dan pihak terkait lainnya jika dipandang perlu".

Dewan Pengupahan Provinsi punya wewenang yang lebih special dari pada Dewan Pengupahan tingkat Kabupaten/ Kota, seperti dalam Permenakertrans No. 13 Tahun 2012 tentang Komponen dan Pelaksanaan Tahapan Pencapaian Kebutuhan Hidup Layak yang mencantumkan halhal yang dapat dilakukan Dewan Pengupahan.

Selain yang diatur dalam Keputusan Presiden No. 107 Tahun 2004, yakni bahwa Dewan Pengupahan Provinsi dan Dewan Pengupahan Kabupaten/ Kota dapat membentuk gugus tugas dalam komisi dan mengatur lebih lanjut tentang tata 
kerjanya, Permenakertrans No. 13 Tahun 2012 juga memberikan peluang kewenangan. Kewenangan melalui Permenakertrans adalah menetapkan kualitas dan spesifikasi teknis masing-masing komponen dan jenis KHL, membentuk tim survey $\mathrm{KHL}$ serta menetapkan nilai KHL.

$$
\text { Dalam rangka proses }
$$

pemberian rekomendasi upah minimum kepada gubernur, Dewan Pengupahan Provinsi mempertimbangkan Kebutuhan hidup layak (KHL), produktivitas dan pertumbuhan ekonomi;

Usulan penetapan upah minimum dirumuskan oleh Dewan Pengupahan Provinsi dengan mempertimbangkan hal-hal diatas dan kemudian disampaikan kepada Gubernur. yang kemudian Upah minimum ditetapkan oleh Gubernur dengan memperhatikan rekomendasi dari Dewan Pengupahan Provinsi dan/atau Bupati/Walikota, demikian ketentuan Pasal 89 ayat (3) UndangUndang No. 13 Tahun 2003 tentang Ketenagakerjaan.

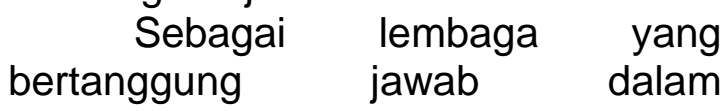
merekomendasikan upah minimum kepada Gubernur, Dewan Pengupahan belum bisa mendorong pemerintah untuk mengeluarkan upah yang layak bagi buruh. Lembaga ini juga "gagal" membuat usulan UMP/UMK yang layak yang bisa diterima buruh. Hal ini disebabkan salah satunya adalah Keanggotaan Dewan Pengupahan mulai tingkat pusat, Provinsi sampai Kab/Kota, unsurnya berasal dari pemerintah, organisasi pengusaha dan serikat pekerja, dengan Komposisi $2: 1: 1$, sedangkan perguruan tinggi jumlahnya disesuaikan dengan kebutuhan yang ada. Dengan komposisi tersebut dalam membuat rekomendasi untuk Gubernur/ Walikota/ Bupati seringkali mengalami deadlock, apabila hal ini terjadi maka dalam membuat rekomendasi dibuat dalam bentuk berita acara yang isinya rekomendasi dari masing-masing unsur (biasanya yang deadlock dari unsur pengusaha dan serikat pekerja).

Berita acara yang berisi rekomendasi masing-masing unsur di dewan pengupahan Kota/Kab. tersebut kemudian diajukan ke Walikota/Bupati untuk dirumuskan besaran upah minimumnya. Usulan upah minimum Kota/Kab. oleh Walikota/Bupati direkomendasikan kepada Gubernur sesuai pasal 46 dan pasal 47 Peraturan Pemerintah No. 78 Tahun 2015 Tentang Pengupahan disebutkan :

Pasal 46

(1) Gubernur dapat menetapkan Upah minimum kabupaten/kota.

(2) Upah minimum kabupaten/kota sebagaimana dimaksud pada ayat (1) harus lebih besar dari Upah minimum provinsi di provinsi yang bersangkutan.

Pasal 47

(1) Penetapan Upah minimum kabupaten/kota sebagaimana dimaksud dalam Pasal 46 dihitung berdasarkan formula perhitungan Upah minimum sebagaimana dimaksud dalam Pasal 44 ayat (2).

(2) Dalam hal telah dilakukan peninjauan kebutuhan hidup layak sebagaimana dimaksud dalam Pasal 43 ayat (5),

\footnotetext{
${ }^{14}$ hasil interview dari anggota dewan pengupahan kota Semarang unsur pekerja Ahmad Zainudin, A.Md
} 

gubernur menetapkan Upah minimum kabupaten/kota dengan memperhatikan rekomendasi bupati/walikota serta saran dan pertimbangan dewan pengupahan provinsi.

(3) Rekomendasi bupati/walikota sebagaimana dimaksud pada ayat (2) berdasarkan saran dan pertimbangan dewan pengupahan kabupaten/kota.

(4) Rekomendasi bupati/walikota serta saran dan pertimbangan dewan pengupahan provinsi sebagaimana dimaksud pada ayat (2) dan saran dan pertimbangan dewan pengupahan kabupaten/kota sebagaimana dimaksud pada ayat (3) didasarkan pada hasil peninjauan kebutuhan hidup layak yang komponen dan jenisnya ditetapkan oleh Menteri dan dengan memperhatikan produktivitas dan pertumbuhan ekonomi.

Rekomendasi KHL dan Upah minimum yang diajukan Walikota/ Bupati kemudian diajukan kepada Gubernur untuk menjadi pertimbangan dalam menetapkan upah minimum, meskipun dewan pengupahan provinsi ikut memberikan arahan serta pertimbangan dalam penetapan upah minimum berdasarkan kewenangan yang dimiliki Gubernur berwenang menetapkan apakah sesuai atau tidak dengan rekomendasi upah minimum dari Walikota/ Bupati yang pasti tidak melebihi nilai upah minimum Kota/Kab. Hal ini yang menjadi kekawatiran kelompok pekerja karena kewenangan Gubernur yang tidak bisa diintervensi tersebut akan berpihak kepada kelompok pengusaha.

\section{B. Rekonstruksi KHL melalui Koperasi Karyawan dalam kajian Undang - Undang No. 13 Tahun 2003}

Perdebatan

mengenai

penetapan UMP dan KHL selalu muncul setiap tahun. Meskipun pemerintah melalui Menteri Tenaga Kerja dan Transmigrasi telah mengeluarkan Permenakertrans No. 13 Tahun 2012 yang mencakup 60 komponen dalam penetapan $\mathrm{KHL}$, namun dalam kenyataannya buruh menilai bahwa jumlah komponen tersebut masih kurang (baca Tabel 2). Disisi lain pengusaha sebagai pihak yang membayar upah menilai komponen terbaru tersebut sudah tepat.

Upah minimum yang seharusnya menjadi jaring pengaman dalam implementasinya dijadikan dasar dalam penetapan upah oleh perusahaan kepada seluruh karyawan. Permenakertrans No.13 Tahun 2012 dalam Pasal 1 disebutkan $\mathrm{KHL}$ standar kebutuhan seorang pekerja/buruh lajang untuk dapat hidup layak secara fisik untuk kebutuhan 1 (satu) bulan. Upah yang dibayar untuk buruh lajang jelas tidak sesuai jika diterapkan terhadap buruh yang sudah berkeluarga. Secara nyata kebutuhan buruh berkeluarga sangat kompleks yang tidak tercantum dalam 60 komponen KHL berdasarkan lampiran 1 Permenakertrans No.13 Tahun 2012, misalnya ketika kita bicara kebutuhan buruh berkeluarga adalah sekolah anak atau kebutuhan-kebutuhan lain sesuai perkembangan zaman yang harus dipenuhi buruh seperti kendaraan bermotor, gadget, kulkas 
dan sebagainya yang tidak mungkin bisa terpenuhi dengan hanya mengharap pada upah minimum berdasarkan standart KHL yang telah ditetapkan.

Pemerintah sebenarnya telah memahami bahwa dengan upah minimum yang telah ditetapkan belum menjawab standart kehidupan yang layak untuk para pekerja, sehingga pada Undang-Undang nomor 13 tahun 2003 tentang ketenagakerjaan dimasukkan pasal 100 dan 101 yang berbunyi:

Pasal 100
(1) Untuk
meningkatkan $\begin{array}{ll}\text { kesejahteraan } & \text { bagi } \\ \text { pekerja/buruh } & \text { dan }\end{array}$ keluarganya, pengusaha wajib menyediakan fasilitas kesejahteraan.
(2) Penyediaan fasilitas kesejahteran sebagaimana dimaksud pada ayat (1), dilaksanakan dengan memperhatikan kebutuhan pekerja/buruh dan ukuran kemampuan perusahaan.
(3) Ketentuan mengenai jens dan kriteria fasilitas kesejahteraan sesuai dengan kebutuhan pekerja/ buruh dan ukuran kemampuan perusahaan sebagaimana dimaksud pada ayat (1) dan ayat (2), diatur dengan Peraturan Pemerintah.

Penjelasan pasal 100 ayat (1) Yang dimaksud dengan fasilitas kesejahteraan antara lain pelayanan keluarga berencana, tempat penitipan anak, perumahan pekerja/buruh, fasilitas beribadah, fasilitas olah raga, fasilitas kantin, fasilitas kesehatan, dan fasilitas rekreasi. Pasal 101

(1) Untuk meningkatkan kesejahteraan pekerja/buruh, dibentuk koperasi pekerja/ buruh dan usaha-usaha produktif di perusahaan.

(2) Pemerintah, pengusaha, dan pekerja/buruh atau serikat pekerja/serikat buruh berupaya menumbuhkembangkan koperasi pekerja/buruh, dan mengembangkan usaha produktif sebagaimana dimaksud pada ayat (1).

(3) Pembentukan koperasi sebagaimana dimaksud pada ayat (1), dilaksanakan sesuai dengan peraturan perundang-undangan yang berlaku.

(4) Upaya-upaya untuk menumbuhkembangkan

koperasi pekerja/ buruh sebagaimana dimaksud pada ayat (2), diatur dengan Peraturan Pemerintah.

Pasal 100 dan 101 UndangUndang nomor 13 tahun 2003 tentang ketenagakerjaan diatas cukup menjelaskan bahwa buruh atau pekerja perlu ditingkatkan kesejahteraannya yaitu dengan mewajibkan pengusaha/ perusahaan menyediakan fasilitas kesejahteraan, dalam kerangka peningkatan kesejahteraan pemerintah memberikan ruang pembentukan koperasi pekerja dan usaha-usaha produktif di perusahaan. 


\section{B.1. Koperasi Sebagai Solusi Pemenuhan KHL Bagi Pekerja}

Ekonomi kerakyatan

merupakan sebuah sistem

perekonomian yang ditujukan untuk mewujudkan kedaulatan rakyat di bidang ekonomi, memiliki prinsip bahwa perekonomian disusun sebagai usaha berdasarkan azas kekeluargaan, serta menginginkan kemakmuran rakyat. Bila dilihat dari definisi diatas, prinsip-prinsip ekonomi kerakyatan bersinergi dengan prinsip - prinsip koperasi.

Dalam konteks ekonomi, kegiatan produksi dan konsumsi dilaksanakan oleh rakyat dan untuk rakyat, sementara pengelolaannya dipimpin oleh rakyat itu sendiri. Begitu juga salah satu prinsip yang dianut oleh koperasi yaitu "pengawasan oleh anggota diselenggarakan secara demokratis", yang mengandung arti koperasi merupakan organisasi demokratis yang diawasi dan dikendalikan oleh anggotanya. Anggota berpartisipasi aktif dalam menentukan kebijakan dan membuat keputusan. Jadi, prinsip demokrasi ekonomi yang dimaksudkan di atas hanya dapat diimplementasikan dalam wadah koperasi yang berazaskan kekeluargaan.

Dari tujuan tersebut, dapat dipahami bersama bahwa koperasi memiliki peranan dalam pembangunan ekonomi berbasis kerakyatan. Koperasi merupakan satu-satunya badan usaha yang sesuai dengan prinsip-prinsip ekonomi kerakyatan yang mengedepankan prinsip kekeluargaan dan kesejahteraan anggota.

Pasal 3 UU No. 25 Tahun 1992 tentang Perkoperasian, tertuang tujuan koperasi Indonesia seperti berikut :

"Memajukan kesejahteraan anggota pada khususnya dan masyarakat pada umumnya serta ikut membangun tatanan perekonomian nasioanal dalam rangka mewujudkan masyarakat yang maju, adil, dan makmur berlandaskan Pancasila dan Undang Undang Dasar 1945"

Sesuai pasal 3 tersebut tujuan koperasi sudah sangat tepat dan apabila diterapkan dalam koperasi karyawan sudah bisa dipastikan akan menjawab serta menunjang kebutuhan hidup layak para pekerja. Koperasi

berdasarkan kepentingannya ada bermacammacam jenisnya seperti koperasi produksi, koperasi konsumen, koperasi jasa, koperasi simpan pinjam, dan sebagainya. Sehingga apabila dikaitkan dengan 60 komponen $\mathrm{KHL}$ lampiran 1 Permenakertrans No.13 Tahun 2012, koperasi karyawan akan menyesuaikan pemenuhan kebutuhan pekerja dengan mekanisme pengelolaan yang disepakati antara perusahaan, pengurus koperasi dan anggotanya.

Penulis mengambil contoh Koperasi karyawan Bitrajaya di PT. Bitratex Industries Semarang ${ }^{15}$, berdasarkan data Kopkar Bitrajaya, Koperasi tidak hanya bisa memenuhi 60 komponen $\mathrm{KHL}$, namun juga bisa memenuhi kebutuhan lain yang

\footnotetext{
${ }^{15}$ Kopkar Bitrajaya didirikan oleh karyawan PT. Bitratex Industries Semarang pada tahun 1986 dan sudah berbadan hukum, sampai sekarang anggotanya mencapai 2200 anggota yang seluruhnya adalah PT. Bitratex Industries Semarang.
} 
dianggap penting oleh pekerja diluar 60 komponen tersebut, bahkan Kopkar Bitrajaya juga menjalankan program simpan pinjam untuk anggota. Pemenuhan kebutuhan oleh Kopkar Bitrajaya kepada pekerja apabila dibandingkan dengan upah minimum kota Semarang yaitu Rp.2.310.087,50,- dimana pekerja harus memenuhi semua kebutuhannya adalah suatu ketidakmungkinan dan menjadi kenyataan ketika pemenuhan kebutuhan pekerja tersebut dilakukan oleh koperasi.

\section{Kerangka Teoretik Rekontruksi KHL melalui Koperasi Karyawan}

Membahas KHL dan Koperasi ada benang merah yang bisa menjadi kata kunci yaitu kesejahteraan dan keadilan. Kesejahteraan yang dimaksud adalah kesejahteraan untuk pekerja yang merupakan anggota koperasi juga dan keadilan bagi pekerja dalam penetapan kebijakan $\mathrm{KHL}$.

Konsep kesejahteraan menurut Nasikun, dapat dirumuskan sebagai padanan makna dari konsep martabat manusia yang dapat dilihat dari empat indicator adalah: Rasa aman (security); Kesejahteraan (welfare); Kebebasan (freedom); Jati diri (Identity). ${ }^{16}$ Kesejahteraan mendapat posisi yang sama dengan 3 indikator lainnya ketika bicara tentang martabat manusia yang harus terpenuhi.

\section{Sedangkan}

menurut

Friedlander, kesejahteraan sosial adalah sistem yang terorganisasi dari pelayanan - pelayanan sosial dan institusi - institusi yang di rancang

${ }^{16}$ Nasikun, Urbanisasi dan Kemiskinan di Dunia Ketiga (Yogyakarta PT. Tiara Wacana, 1996), hlm. 70. untuk membantu individu-individu dan kelompok-kelompok guna mencapai standar hidup dan kesehatan yang memadai dan relasi-relasi personal dan sosial sehigga memungkinkan mereka dapat mengembangkan kemampuan dan kesejahteraan sepenuhnya selaras dengan kebutuhan keluarga dan masyarakatnya. ${ }^{17}$

Mengacu pada pendapat Nasikun dan Friedlander, amanat kesejahteraan telah teradopsi pada Undang-Undang No. 13 tahun 2003 tentang ketenagakerjaan dan UndangUndang No. 25 Tahun 1992 tentang Perkoperasian yaitu penetapan upah minimum diarahkan kepada pencapaian kebutuhan hidup layak dan tujuan koperasi adalah untuk mensejahterakan anggotannya.

Namun apabila kita bicara tentang keadilan hal ini menjadi suatu penerimaan yang relatif, adalah sesuatu yang mutlak bahwa keadilan harus ditegakkan namun keadilan yang bagaimana yang harus ditegakkan serta keadilan dari sudut pandang siapa yang harus ditegakkan?

Keadilan merupakan suatu hasil pengambilan keputusan yang mengandung kebenaran, tidak memihak, dapat dipertanggung jawabkan dan memperlakukan setiap manusia pada kedudukan yang sama didepan hukum. Perwujudan keadilan dapat dilaksanakan dalam ruang lingkup kehidupan masyarakat, bernegara dan kehidupan masyarakat internasional, ditunjukkan melalui sikap dan perbuatan yang tidak berat sebelah dan memberikan sesuatu kepada orang lain yang menjadi

\footnotetext{
17 Ibid, hlm. 9
} 
haknya. ${ }^{18}$ Keadilan dapat juga diartikan sebagai suatu tindakan yang didasarkan pada norma-norma, baik norma agama maupun norma hukum.

Hans Kelsen berpendapat keadilan dapat dimaknai sebagai legalitas, Keadilan dalam arti legalitas adalah suatu kualitas yang tidak berhubungan dengan isi tata aturan positif, tetapi dengan pelaksanaannya. Menurut legalitas, pernyataan bahwa tindakan individu adalah adil atau tidak adil berarti legal atau ilegal, yaitu tindakan tersebut sesuai atau tidak dengan norma hukum yang valid untuk menilai sebagai bagian dari tata hukum positif. Hanya dalam makna legalitas inilah keadilan dapat masuk ke dalam ilmu hukum. ${ }^{19}$

Ditetapkannya upah minimum dan KHL oleh Gubernur setidaknya harus memenuhi rasa keadilan yang obyektif, mengapa keadilan obyektif ini perlu disampaikan karena sering kali keadilan diputuskan hanya semata-mata mencari jalan tengah meskipun tidak mengikuti kebenaran obyektif. Misalnya ketika tidak ada kesepahaman tentang rumusan $\mathrm{KHL}$ dan usulan upah minimum dari unsur serikat pekerja dan pengusaha di dewan pengupahan maka masingmasing rekomendasi dari unsur serikat pekerja dan pengusaha akan dibuatkan berita acara dan diajukan kepada Gubernur, selanjutnya kebiasaan yang sudah terjadi pemerintah mengambil nilai tengah-

${ }^{18}$ Sudikno Mertokusumo dalam H. Salim HS, 2010, Perkembangan Teori Dalam IImu Hukum, PT Rajagrafindo Persada, Jakarta, hIm. 82.

${ }^{19}$ Ibid, hlm 23 tengah antara usulan serikat pekerja dan asosiasi pengusaha. ${ }^{20}$

IV. KESIMPULAN

1. Pekerja/ buruh berhak atas upah layak hal tersebut di atur di dalam undang - undang No.13 tahun 2003 tentang ketenagakerjaan. Upah layak selanjutnya ditetapkan oleh gubernur dengan rumusan: kebutuhan hidup layak dengan memperhatikan pertumbuhan ekonomi dan inflasi, hal tersebut sesuai dengan PP No. 78 tahun 2015 tentang pengupahan dalam permenaker No.21 tahun 2016 tentang kebutuhan hidup layak sebagai aturan pelaksana dari PP No.78 tahun 2015 tentang pengupahan. Kebutuhan hidup layak yang dimaksud adalah upah tahun berjalan, sementara inflasi dan pertumbuhan ekonomi adalah data dari BPS. Kebutuhan hidup layak dirumuskan oleh dewan pengupahan kabupaten/kota dan dewan pengupahan provinsi yang direkomendasikan kepada gubernur sebagai dasar pertimbangan penetapan upah. Dewan pengupahan terdiri dari unsur: pekerja, pengusaha, pemerintah dan akademisi/pakar, dalam menetapkan kebutuhan hidup layak dewan pengupahan melakukan sidang pleno untuk mendengarkan pendapat dan usulan masing - masing unsur yang hasilnya menjadi sebuah

\footnotetext{
${ }^{20}$ hasil interview dari anggota dewan pengupahan kota Semarang unsur pekerja Ahmad Zainudin, A.Md
} 


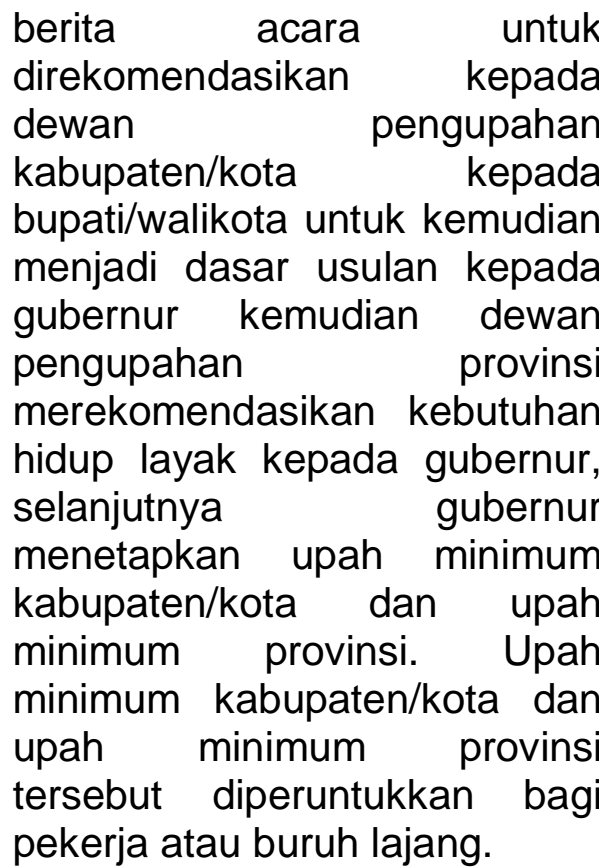

2. Koperasi memiliki peranan dalam pembangunan ekonomi berbasis kerakyatan, koperasi merupakan satu - satunya badan usaha yang sesuai prinsip - prinsip ekonomi kerakyatan yang mengedepankan prinsip kekeluargaan dan kesejahteraan anggota. Dalam upaya meningkatkan kesejahteraannya,

pekerja/buruh dapat membentuk koperasi karyawan yang difasilitasi oleh pengusaha hal tersebut sesuai dengan ketentuan pasal 101 undang - undang no.13 tahun 2003 tentang ketenagakerjaan . keberadaan koperasi karyawan tidak hanya bisa memenuhi komponen kebutuhan hidup yang dimaksud didalam PP No.78 tahun 2015 tentang pengupahan Jo. Permenaker No.21 tahun 2016 tentang Kebutuhan hidup layak tetapi keberadaan koperasi karyawan juga dapat menjawab kebutuhan hidup riil pekerja dan keluarganya diluar komponen kebutuhan hidup layak.

\section{SARAN}

1. Seharusnya perumusan KHL sebagai dasar penetapan upah dilakukan dengan mekanisme survey yang objektif (menyangkut tempat, waktu dan merk barang) oleh dewan pengupahan terhadap seluruh komponen $\mathrm{KHL}$ mengingat harga setiap komponen kebutuhan terjadi fluktuasi dalam setiap waktu. Di samping itu Gubernur dalam menetapkan upah juga harus mengacu kepada 100\% hasil survey dewan pengupahan dengan mempertimbangkan prediksi inflasi tahun upah diberlakukan. Di sisi lain dalam rangka meningkatkan kesejahteraan buruh pemerintah perlu bertindak tegas terhadap pengusaha agar benar - benar dapat memfasilitasi karyawannya dalam membentuk koperasi sebagaimana mandat dalam pasal 101 undang - undang No.13 tahun 2003 tentang ketenagakerjaan.

2. Sebagai upaya untuk mensejahterakan anggotanya yang notabene pekerja maka seharusnya koperasi karyawan harus bisa mengembangkan usahanya untuk melakukan kerjasama dengan pengusaha dan lembaga - lembaga keuangan/ pembiayaan agar bisa lebih berkembang/ maju 
serta dapat memenuhi kebutuhan hidup anggotanya, baik kebutuhan sandang, pangan, perumahan, transportasi, pendidikan dan sosial.

3. Dalam membentuk sebuah koperasi yang berbadan hukum syarat dan ketentuannya cukup didirikan oleh 20 (dua puluh)

DAFTAR PUSTAKA

A. BUKU - BUKU

Adrian Sutedi, 2011, Hukum Perburuhan, Sinar Grafika, Jakarta.

Indroharto, 1993, Usaha Memahami UndangUndang Tentang Peradilan Tata Usaha Negara, Pustaka Harapan, Jakarta.

Lalu Husni, 2010, Hukum Ketenagakerjaan Indonesia, Edisi Revisi, Rajawali Pers, Jakarta. Nasikun, 1996, Urbanisasi dan Kemiskinan di Dunia Ketiga, PT. Tiara Wacana, Yogyakarta.

Simanjuntak Payaman J, 1985, Pengantar Ekonomi orang dalam membentuk kepengurusan. Untuk itu seharusnya para pekerja/ buruh harus berani untuk bersama sama mendirikan koperasi karyawan sebagai upaya gotong royong dalam meningkatkan kesejahteraan pekerja/buruh.

Sumber Daya Manusia, Lembaga Penerbit Fakultas Ekonomi Universitas Indonesia, Jakarta.

Sudikno Mertokusumo dalam H. Salim HS, 2010, Perkembangan Teori Dalam IImu Hukum, PT Rajagrafindo Persada, Jakarta.

Tulus T,H, Tambunan, 2015, Globalisasi dan Perdagangan Internasional, Ghalia Indonesia, Jakarta.

B. UNDANG - UNDANG

Permenakertas

No.17/Men/VIII/2005

UU. No. 13 tahun 2003 tentang

Ketenagakerjaan 